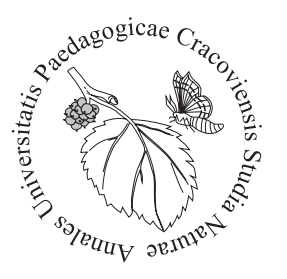

Sylwia Śliwińska-Wilczewska*, Arkadiusz Knitter, Daria Cisło, Adam Latała Institute of Oceanography, University of Gdansk, Gdynia, Poland; *ocessl@edu.pl

\title{
Allelopathic activity of the Baltic picocyanobacterium Synechocystis sp.
}

\section{Introduction}

The term "allelopathy" as first defined by Molisch (1937), who indicated that these are positive or negative biochemical interactions between plants. Rice (1979) included into this definition the interaction between micro-organisms, and Inderjit and Dakshini (1994) indicated that allelopathic activity is also present in the aquatic environment, especially between phytoplankton species.

Allelopathic interaction is widespread and can occur in all aquatic ecosystems (Gross, 2003). Moreover, cyanobacterial allelopathy can be found in all aquatic environments where these primary producers are able to release active allelopathic compounds which can affect the functioning of the whole ecosystem (Żak, Kosakowska, 2015). Production of these allelopathic compounds is an important adaptation by which some cyanobacteria can achieve a competitive advantage over other primary producers (Poniedziałek et al., 2015). Allelopathy may be also one of the factors affecting the formation of massive and harmful cyanobacterial blooms in aquatic environments. Over the past few decades, the world's coastal waters have experienced an increase in the number of harmful bloom events (Anderson et al., 2012). Recent studies indicate that blooms of picocyanobacteria have grown significantly in the last decades (Sorokin, Zakuskina, 2010), so it is important to determine the allelopathic interactions between the dominant species of picocyanobacteria.

The production and release of allelopathic compounds is an intriguing concept in which substances are secreted by the interacting species. Cyanobacteria are effective producers of many bioactive metabolites, including both acute toxins and allelopathic compounds (Burja et al., 2001; Berry et al., 2008; Leão et al., 2012). Mazur-Marzec et al. (2015) described Baltic cyanobacteria as a rich source of novel metabolites, e.g., curacin $\mathrm{A}$, apratoxin $\mathrm{D}$, dolastatin 10 and largazole, and different peptides, e.g., anabaenopeptins, cyanopeptolins, aeruginosins, spumigins, and nostocyclopeptides. However, 
many of cyanobacteria remain unknown. Moreover, production of allelopathic substances is common, but not identical for all species forming massive blooms, and there are no clear reasons for the synthesis of these compounds (Gross, 2003; Legrand et al., 2003). It is possible that their function enables the deterrence of predators and the inhibition of co-occurring species of phytoplankton (Liu et al., 2010). In addition, it is suggested that in the Baltic Sea cyanobacterial allelopathy may cause their dominance after the maximum concentration of cells is formed by environmental factors (Suikkanen et al., 2004). Moreover, available studies indicate that the Baltic cyanobacteria may be allelopathic to other species, and this effect is dependent not only on the selected species, but even a strain of cyanobacteria (Śliwińska et al., 2011). The use of biological tests is the first step in identifying which group of allelopathic compounds is responsible for causing harmful effects in the aquatic environment (Fistarol et al., 2004).

The main aim of this study was to estimate the allelopathic interaction between different Baltic strains of picocyanobacteria of the genus Synechocystis. In this study, the influence of allelopathic compounds on the growth of analysed species was investigated in monocultures and in mixed cultures. These results indicate that the allelopathic effect of Synechocystis sp. may be connected with the formation of a massive cyanobacterial bloom of these organisms in many aquatic ecosystems.

\section{Material and methods}

The experiments were conducted on the three strains of the picocyanobacteria of the genus Synechocystis (BA-121, BA-122 and BA-153) (Fig. 1). The strains were isolated from the coastal zone of the Gulf of Gdańsk (southern Baltic Sea) and are maintained as uni-algal cultures in the Culture Collection of Baltic Algae (CCBA) at the Institute of Oceanography, University of Gdańsk, Poland (Latała et al., 2006). The tests on the 'batch cultures' were carried out in $25 \mathrm{~mL}$ glass Erlenmeyer flasks containing sterilised f/2 medium (Guillard, 1975). The media were prepared from Baltic water with a salinity of 8 psu, which was filtered through Whatman GF/C glass fibre filters, and autoclaved. Analysed picocyanobacteria were grown 7 days in constant conditions of $20^{\circ} \mathrm{C}$ and $8 \mathrm{psu}$, under a 16:8 h light:dark cycle at $10 \mu \mathrm{mol}$ photons $\mathrm{m}^{-2} \mathrm{~s}^{-1}$ and these were the control treatment conditions. Fluorescent lamps (Cool White 40W, Sylvania, USA) were used as a source of irradiance. The intensity of PAR was measured using a LI-COR quantum-meter with a cosine collector. The donor and target picocyanobacteria were acclimated to these culture conditions for 7 days; afterwards, actively growing cultures were used for the establishment of the allelopathic experiment.

Allelopathic interactions in monocultures were determined by using the modified method proposed by Suikkanen et al. (2004). Allelopathic interaction was studied by adding the filtrate obtained from picocyanobacterial culture of 


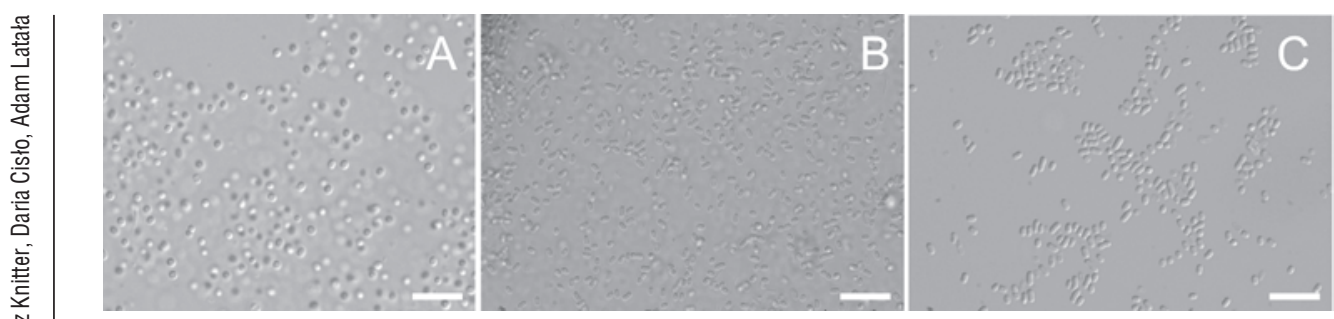

Fig. 1. Picocyanobacterial strains of the genus Synechocystis used in this study: A) BA-121, B) BA-122 and C) BA-153. Scale bars $=10 \mu \mathrm{m}$

Synechocystis sp. BA-153 to tested picocyanobacteria Synechocystis sp. BA-121 and BA-122. The culture of BA-153 was filtered through $0.45-\mu$ m pore size Macherey-Nagel MN GF-5 filters. The cell-free filtrate $(\mathrm{V}=2 \mathrm{~mL})$ was added to $25 \mathrm{~mL}$ Erlenmeyer flasks containing the tested cyanobacteria $(\mathrm{V}=20 \mathrm{~mL})$. In all experiments, the ratio of picocyanobacterium to target species in Erlenmeyer flasks was adjusted to $1: 1$ based on the chlorophyll $a(\mathrm{Chl} a$ ) content (final Chl $a$ concentration in the experimental cultures was $0.4 \mu \mathrm{g} \mathrm{Chl} a \mathrm{~mL}^{-1}$ ). Control samples were prepared by adding mineral medium $\mathrm{f} / 2$ with a volume equal to the added cell-free filtrate. The number of cells in the experimental cultures was determined after the $1^{\text {st }}$ and $7^{\text {th }}$ day of the cyanobacteria exposure to the picocyanobacterial filtrate. Tests were conducted in triplicate and all analysed species were obtained from the early exponential growth phase.

Allelopathic interactions in mixed cultures were determined by using the modified method proposed by Ji et al. (2011). Allelopathic activity was studied by adding the culture of donor picocyanobacteria Synechocystis sp. BA-153 to the tested organisms: Synechocystis sp. BA-121 or BA-122. In all experiments, the final $\mathrm{Chl} a$ concentration in the experimental cultures was $0.4 \mu \mathrm{g} \mathrm{Chl} a \mathrm{~mL}^{-1}$. The culture of donor picocyanobacteria $(\mathrm{V}=2 \mathrm{~mL}$ ) was added to $25 \mathrm{~mL}$ Erlenmeyer flasks containing the tested cyanobacteria $(\mathrm{V}=20 \mathrm{~mL})$. As controls, both Synechocystis sp. BA-121 and BA-122 were cultured individually. Controls consisted in the addition of $2 \mathrm{~mL}$ of filtrated f/2 medium to $25 \mathrm{~mL}$ Erlenmeyer flasks containing $20 \mathrm{~mL}$ of cell suspensions of the same cyanobacteria species. We measured the change in the density of target picocyanobacteria by directly counting the number of cells after the $1^{\text {st }}$ and $7^{\text {th }}$ day. Three replicate flasks were used for each treatment, and all analysed species were obtained from the early exponential growth phase. The experiments lasted 7 days.

The number of cells was counted using flow cytometer BD Accuri ${ }^{\mathrm{m}}$ C6 Plus (Fig. $2,3)$. Events are recorded in list mode. To avoid generating large files, samples can be run for 40 s at a delivery rate of $14 \mu \mathrm{min}^{-1}$, and the number of events is kept at less than 1.000 per second. Events are recorded in standard filters: 670 LP (Detector FL3) and 675/25 (Detector FL4) (Marie et al., 2005). 

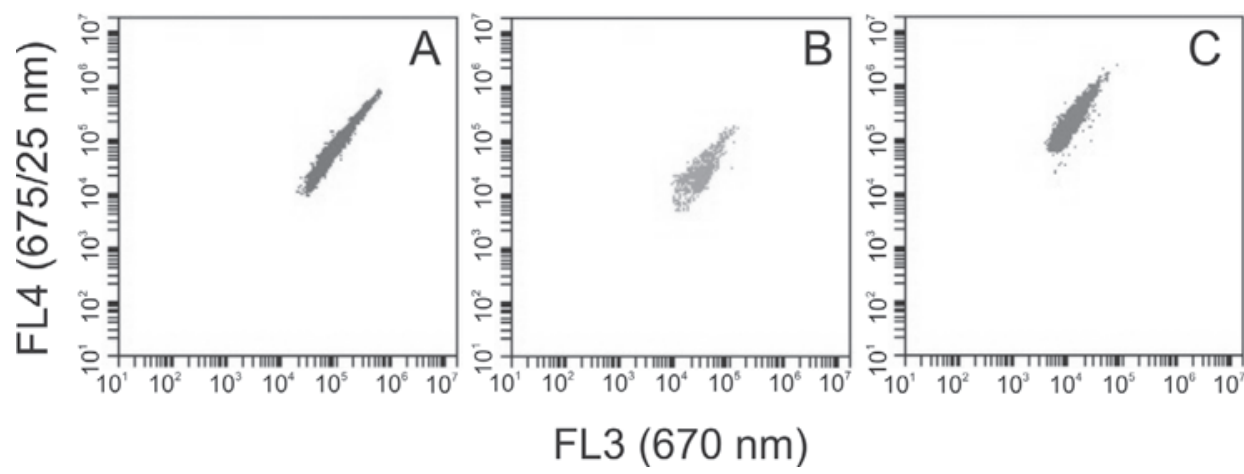

Fig. 2. Cytograms obtained with monocultures of three picocyanobacterial strains of the genus Synechocystis: A) BA-121, B) BA-122 and C) BA-153 analysed using a BD Accuri ${ }^{\text {Tw }}$ C6 Plus flow cytometer

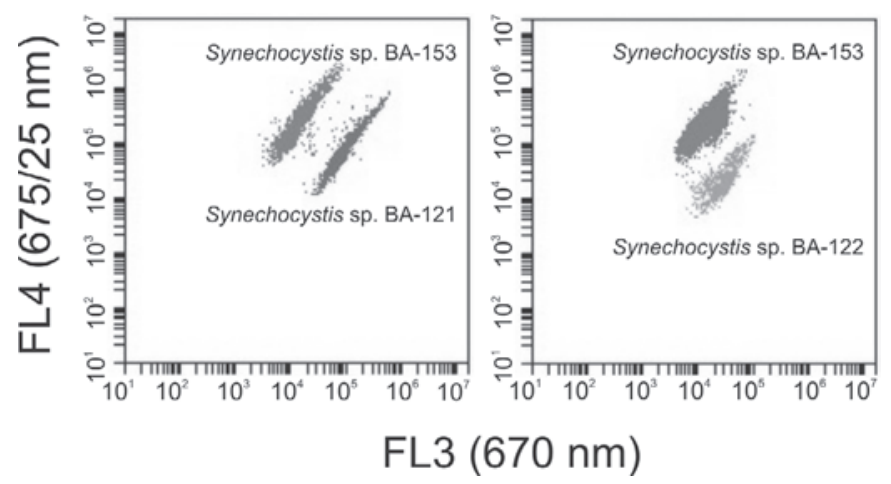

Fig. 3. Cytograms obtained with mixed cultures of picocyanobacterial strains of the genus Synechocystis analysed using a BD Accuri ${ }^{\text {min }}$ C6 Plus flow cytometer

Analysis of variance (ANOVA) was used to test for differences in analysed parameters between the target cultures treated with picocyanobacterial cell-free filtrates or living cells and the control over the experimental period. A post hoc test (Tukeys HSD) was used to show which treatments for growth significantly differed from the control and from each other. Data are reported as mean \pm standard deviation (SD). Levels of significance were ${ }^{\star} \mathrm{p}<0.05$. The statistical analyses were performed using the Statistica 13.1 software.

Results

The effect of the cell-free filtrate addition obtained from strain of Synechocystis BA-153 on the growth of Synechocystis BA-121 and BA-122 after 1 and 7 days of exposition to the filtrates are shown in figure 4 . The results demonstrated that the addition of 
cell-free filtrate from BA-153 decreased the number of cells of BA-121 compared to their control. After the first day of the experiment, for a filtrate addition obtained from Synechocystis sp. BA-153 growth inhibition of Synechocystis sp. BA-121 expressed as a percent of culture density ( $\%$ of control) constituted $45 \%(\mathrm{p}<0.05)$. On the other hand, it was found that the addition of filtrate obtained from Synechocystis sp. BA-153 did not affect the number of cells of Synechocystis sp. BA-121 after 7 day of exposition ( $p>0.05$; Fig. 4A). In addition, it was observed that the cell-free filtrate obtained from Synechocystis sp. BA-153 did not affect the number of cells of Synechocystis sp. BA-122 ( $\mathrm{p}>0.05$, Fig. 4B).
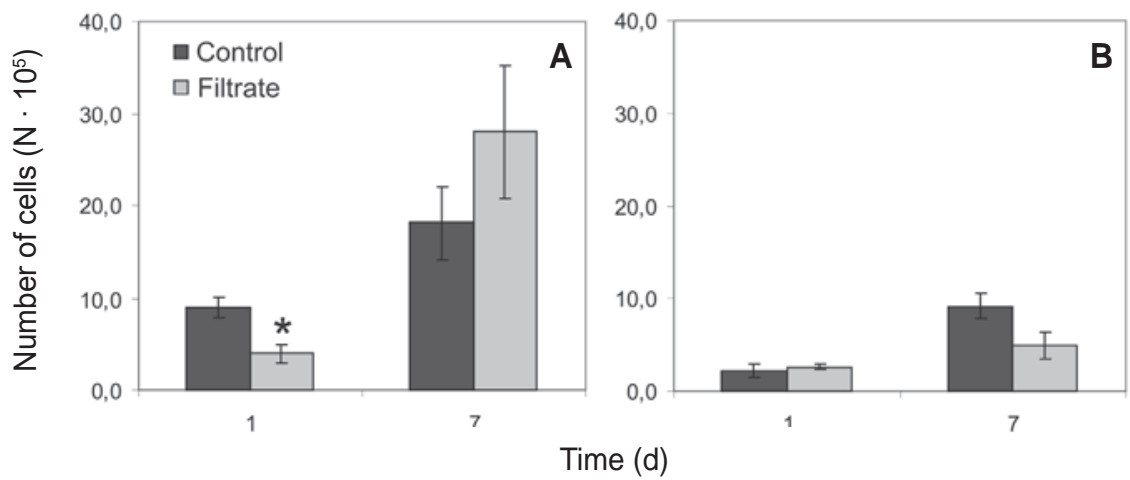

Fig. 4. The effect of the addition of cell-free filtrate from Synechocystis sp. BA-153 cultures on the growth of A) Synechocystis sp. BA-121 and B) Synechocystis sp. BA-122 after $1^{\text {st }}$ and $7^{\text {th }}$ day of exposition, expressed as a number of cells $(\mathrm{N})$. The values refer to means $(\mathrm{n}=3$, mean $\pm \mathrm{SD})$. Asterisk indicates significant difference compared with control $(\mathrm{p}<0.05)$
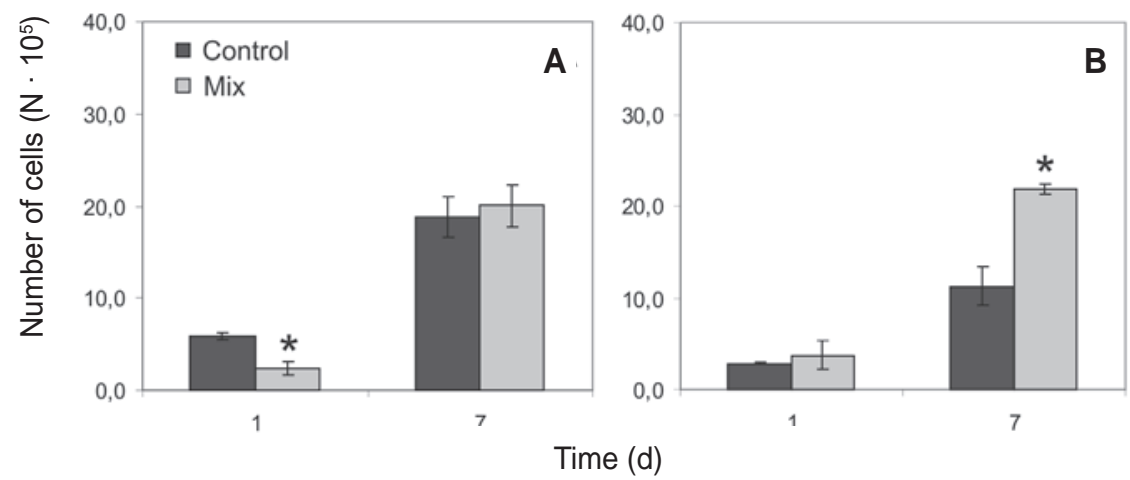

Fig. 5. The effect of the addition of living cells from Synechocystis sp. BA-153 cultures on the growth of A) Synechocystis sp. BA-121 and B) Synechocystis sp. BA-122 after $1^{\text {st }}$ and $7^{\text {th }}$ day of exposition, expressed as a number of cells $(\mathrm{N})$. The values refer to means $(\mathrm{n}=3$, mean $\pm \mathrm{SD})$. Asterisk indicates significant difference compared with control $(\mathrm{p}<0.05)$ 
After the addition of live cells of the strain Synechocystis BA-153 to Synechocystis BA-121 culture, the decline in growth was observed (Fig. 5A). On the $1^{\text {st }}$ day of the experiment, the minimum cell response of Synechocystis sp. BA-121 constituted 40\% $(\mathrm{p}<0.05)$ in comparison to the control treatment. On the other hand, the addition of live cells of strain Synechocystis BA-153 culture stimulated the growth of Synechocystis sp. BA-122, and at $7^{\text {th }}$ day of experiment growth increased by $94 \%$ relative to control $(\mathrm{p}<0.05$, Fig. 5B)

\section{Discussion}

The study of the allelopathy phenomenon focuses mainly on understanding the effects of allelopathic compounds on a variety of target organisms. The modes of the action of allelochemicals depend on the nature of the interaction between donor and target organisms and the activity of these compounds. There are some reports of allelopathic effects, such as growth stimulation or inhibition caused by different cyanobacteria (Suikkanen et al., 2006), but no information about the allelopathic potential of Baltic picocyanobacterium of genus Synechocystis on co-existing picocyanobacterial strains has been found. Therefore, the main goal of this study was to investigate the influence of metabolites obtained from picocyanobacterium Synechocystis sp. in monocultures and in mixed cultures.

In most cases, allelopathic compounds cause the death of target organisms or reduce their growth rate and biomass (Rzymski et al., 2014). Moreover, inhibition of the growth of the target organism by production allelopathic compounds is relatively widespread and the most frequently reported mode of action of cyanobacteria (Issa, 1999; Schagerl et al., 2002). In this study, we have demonstrated that the picocyanobacterium strain of the genus Synechocystis BA-153 caused allelopathic effects against other strains of picocyanobacteria. It was found that strain BA-121 was strongly inhibited by strain BA-153 in both the mixed culture and cell-free filtrates. Picocyanobacteria plays an important role in aquatic ecosystems but not much is known about their allelopathic activity. Information about the ability to allelopathic interactions of other picocyanobacterium Synechococcus sp. was described by Śliwińska-Wilczewska et al. (2016a). In this study, the authors showed that the addition of the cell-free filtrate obtained from the Baltic picocyanobacterium Synechococcus sp. had a significant inhibitory effect on Nodularia spumigena. Additionally, Śliwińska-Wilczewska et al. (2016b) showed the sensitivity of the diatom Navicula perminuta to allelopathic compounds produced by this picocyanobacterium. In this study, it was demonstrated that analysed picocyanobacterium reveals allelopathic activity that was regulated by the intensity of light, temperature, and salinity. Śliwińska et al. (2011) also showed that all analysed strains of Synechococcus sp. demonstrated the allelop- 
athic activity and significantly decreased the number of cells of Chlorella vulgaris. The authors concluded that all three strains of Baltic picocyanobacterium from the genus Synechococcus (BA-120, BA-124, and BA-132) showed allelopathic activity; however, the BA-124 strain had the greatest negative impact on the growth of analysed green algae C. vulgaris. Moreover, Martins et al. (2008) describe the biological activities of marine cyanobacteria strains belonging to the genus Synechocystis and Synechococcus isolated from Atlantic coast of Portugal. The authors screened marine picocyanobacterial secondary metabolites for cytotoxic activity using primary rat hepatocytes and human HL-60 cells. In this study, the authors showed that marine picocyanobacterial strains of the genus Synechocystis and Synechococcus produce substances with inhibitory effects on prokaryotic cells and with apoptotic activity in eukaryote cell lines. Moreover, Hamilton et al., (2014) demonstrated a significant effect of Synechococcus strain on dark preference of black perch Embiotoca jacksoni. Costa et al. (2015) demonstrated that marine picocyanobacterium Cyanobium sp. inhibited Nannochloropsis sp. growth. Moreover, Paz-Yepes et al. (2013) have found a clear growth impairment of two strains of Synechococcus sp. (CC9311 and WH8102) when they are cultured in the presence of Synechococcus sp. CC9605. It is believed that selective inhibition of the growth of the target organism may affect the succession of selected cyanobacteria in an aquatic ecosystem (Legrand et al., 2003). Our results showed that Synechocystis allelopathy should be considered when estimating the potential interactions between picocyanobacteria in aquatic ecosystems. Moreover, the results may in part explain the reasons for achieving a competitive advantage of picocyanobacterium Synechocystis in many aquatic ecosystems, including the Baltic Sea.

It was also found that the addition of live cells of picocyanobacterium strain BA-153 stimulated the growth of Synechocystis sp. BA-122. Suikkanen et al. (2005) also indicated that cyanobacteria may stimulate natural plankton assemblages. The authors showed that cyanobacterial filtrates stimulated other cyanobacteria in the community. The numbers of Snowella sp. and Pseudanabaena sp. were significantly higher in all cyanobacterial treatments than in the control. Moreover, the addition of N. spumigena filtrate significantly increased the numbers of both N. spumigena and Anabaena sp. and Aphanizomenon sp. filtrate and caused an over 50-fold increase in the cell numbers of Aphanizomenon sp. in the community. In the present study, picocyanobacterial exudates had the stimulatory effects on the growth of other picocyanobacterium from the same genus. This suggests that the cyanobacteria released some autostimulatory, which accelerated the growth of the same and related species.

Our results confirm that the picocyanobacterium Synechocystis sp. BA-153 is able to produced allelopathic compounds. Unfortunately, information on which metabolites mediate this and many other known allelopathic interactions are still scarce (Leão et 
al., 2012). The identification and isolation of the compounds responsible for the allelopathic effect detected in Synechocystis sp. in our studies will require further research.

These results showed the allelopathic activity of Baltic Synechocystis, which either causes the inhibition or stimulation of the growth of selected picoplanktonic cyanobacteria. Many studies indicated that cyanobacteria produced a wide spectrum of secondary metabolites (e.g., Berry et al., 2008). It is believed that allelopathy may be one of the important factors affecting the formation of massive cyanobacterial blooms in aquatic environments (Gross, 2003; Legrand et al., 2003). Despite the seriousness of the problem, relatively little is known about the allelopathic effect between picocyanobacteria in the Baltic Sea. To evaluate the significance of the allelopathy phenomenon, more detailed studies are needed about the production and secretion of active allelopathic compounds in order to better understand the mechanisms of their effects on the surrounding ecosystem.

\section{Acknowledgements}

The authors would like to thank the anonymous reviewers for their valuable comments and suggestions to improve the quality of the paper. This study was supported by BMN grants, Poland, no. 538-G245-B568-17.

\section{References}

Anderson, D.M., Cembella, A.D., Hallegraeff, G.M. (2012). Progress in understanding harmful algal blooms: Paradigm shifts and new technologies for research, monitoring, and management. Annual Review of Marine Science, 4, 143-176. DOI: 10.1146/annurev-marine-120308-081121

Berry, J.P., Gantar, M., Perez, M.H., Berry, G., Noriega, F.G. (2008). Cyanobacterial Toxins as Allelochemicals with Potential Applications as Algaecides, Herbicides and Insecticides. Marine Drugs, 6, 117 146. DOI:10.3390/md20080007

Burja, A.M., Banaigs, B., Abou-Mansour, E., Burgess, J.G., Wright, P.C. (2001). Marine cyanobacteria - a prolific source of natural products. Tetrahedron, 57,9347-9377. DOI: 10.1016/S0040-4020(01)00931-0

Costa, M.S., Costa, M., Ramos, V., Leão, P.N., Barreiro, A., Vasconcelos, V., Martins, R. 2015. Picocyanobacteria from a clade of marine cyanobium revealed bioactive potential against microalgae, bacteria, and marine invertebrates. Journal of Toxicology and Environmental Health, Part A, 78(7), 432-442. DOI: $10.1080 / 15287394.2014 .991466$

Fistarol, G.O., Legrand, C., Selander, E., Hummert, C., Stolte, W., Granéli, E. 2004. Allelopathy in Alexandrium spp.: effect on a natural plankton community and on algal monocultures. Aquatic Microbial Ecology, 35, 45-56.

Gross, E.M. (2003). Allelopathy of Aquatic Autotrophs. Critical Reviews in Plant Sciences, 22, 313-339. DOI: $10.1080 / 713610859$

Guillard, R.R.L. (1975). Culture of phytoplankton for feeding marine invertebrates. In: W.L. Smith, M.H. Chanley (eds.), Culture of Marine Invertebrate Animals. New York, USA: Plenum Press, 26-60.

Hamilton, T.J., Paz-Yepes, J., Morrison, R., Palenik, A.B., Tresguerres, M. (2014). Exposure to bloom-like concentrations of two marine Synechococcus cyanobacteria (strains CC9311 and CC9902) differentially alters fish behaviour. Conservation Physiology, 2(1), cou020. DOI: 10.1093/conphys/cou020

Inderjit, K., Dakshini, M.M. (1994). Algal Allelopathy. The Botanical Review, 60(2), 182-196.

Issa, A.A. (1999). Antibiotic production by the cyanobacteria Oscillatoria angustissima and Calothrix parietina. Environmental Toxicology and Pharmacology, 8, 33-37. DOI: 10.1016/S1382-6689(99)00027-7 
Ji, X.Q., Han, X.T., Zheng, L., Yu, Z.M., Yang, B.J., Zou, J.Z. (2011). Allelopathic interactions between Prorocentrum micans and Skeletonema costatum or Karenia mikimotoi in laboratory cultures. Chinese Journal of Oceanology and Limnology, 29(4), 840-848. DOI: 10.1007/s00343-011-0512-x

Latała, A., Jodłowska, S., Pniewski, F. (2006). Culture Collection of Baltic Algae (CCBA) and characteristic of some strains by factorial experiment approach. Archiv für Hydrobiologie, 165, Algological Studies, 122, 137-154. DOI: 10.1127/1864-1318/2006/0122-0137

Leão, P.N., Engene, N., Antunes, A., Gerwick, W.H., Vasconcelos, V. (2012). The chemical ecology of cyanobacteria. Natural Product Reports, 29, 372-391. DOI: 10.1039/C2NP00075J

Legrand, C., Rengefors, K., Fistarol, G.O., Granéli, E. (2003). Allelopathy in phytoplankton - biochemical, ecological and evolutionary aspects. Phycologia, 42(4), 406-419. DOI: 10.2216/i0031-8884-424-406.1

Liu, J., Van Rijssel, M., Yang, W., Peng, X., Lü, S., Wang, Y., Chen, J., Wang, Z., Qi, Y. 2010. Negative effects of Phaeocystis globosa on microalgae. Chinese Journal of Oceanology and Limnology, 28(4), 911-916. DOI: $10.1007 /$ s00343-010-9061-y

Marie, D., Simon, N., Vaulot, D. (2005). Phytoplankton cell counting by flow cytometry. Algal culturing techniques, 1, 253-267.

Martins, R.F., Ramos, M.F. Herfindal, L. Sousa, J.A., Skærven, K., Vasconcelos V.M. (2008). Antimicrobial and Cytotoxic Assessment of Marine Cyanobacteria - Synechocystis and Synechococcus. Marine Drugs, 6(1), 1-11. DOI: 10.3390/md6010001

Mazur-Marzec, H., Błaszczyk, A., Felczykowska, A., Hohlfeld, N., Kobos, J., Toruńska-Sitarz, A., Devi, P., Montalvão, S., D’souza, L., Tammela, P., Mikosik, A., Bloch, S., Nejman-Faleńczyk, B., Węgrzyn, G. (2015). Baltic cyanobacteria - a source of biologically active compounds. European Journal of Phycology, 50, 343-360. DOI: 10.1080/09670262.2015.1062563

Molisch, H. (1937). Der einfluss einer pflanze auf die andere - Allelopathie. Jena: G. Fisher, Verlag, p. 160.

Paz-Yepes, J., Brahamsha, B., Palenik, B. (2013). Role of a Microcin-C-like biosynthetic gene cluster in allelopathic interactions in marine Synechococcus. Proceedings of the National Academy of Sciences, 110, 12030-12035. DOI: 10.1073/pnas.1306260110

Poniedziałek, B., Rzymski, P., Kokociński, M., Karczewski, J. (2015). Toxic potencies of metabolite(s) of noncylindrospermopsin producing Cylindrospermopsis raciborskii isolated from temperate zone in human white cells. Chemosphere, 120, 60-614. DOI: 10.1016/j.chemosphere.2014.09.067

Rice, E.L. (1979). Allelopathy - an update. Botanical Review, 45, 15-109.

Rzymski, P., Poniedziałek, B., Kokociński, M., Jurczak, T., Lipski, D., Wiktorowicz, K. (2014). Interspecific allelopathy in cyanobacteria: Cylindrospermopsin and Cylindrospermopsis raciborskii effect on the growth and metabolism of Microcystis aeruginosa. Harmful. Algae, 35, 1-8. DOI: 10.1016/j. hal.2014.03.002

Schagerl, M., Unterrieder, I., Angeler, D.G. (2002). Allelopathy among Cyanoprokaryota and Other Algae Originating from Lake Neusiedlersee (Austria). International Review of Hydrobiology, 87, 365-374. DOI: 10.1002/1522-2632(200207)87:4<365::AID-IROH365>3.0.CO;2-B

Sorokin, Y.I., Zakuskina, O.Y. (2010). Features of the Comacchio ecosystem transformed during persistent bloom of picocyanobacteria. Journal of Oceanography, 66(3), 373-387. DOI: 10.1007/s10872010-0033-9

Suikkanen, S., Fistarol, G.O., Granéli, E. (2004). Allelopathic effects of the Baltic cyanobacteria Nodularia spumigena, Aphanizomenon flos-aquae and Anabaena lemmermannii on algal monocultures. Journal of Experimental Marine Biology and Ecology, 308, 85-101. DOI: 10.1016/j.jembe.2004.02.012

Suikkanen, S., Fistarol, G.O., Granéli, E. (2005). Effects of cyanobacterial allelochemicals on a natural plankton community. Marine Ecology Progress Series, 287, 1-9. 
Suikkanen, S., Engström-Öst, J., Jokela, J., Sivonen, K., Viitasalo, M. (2006). Allelopathy of Baltic Sea cyanobacteria: no evidence for the role of nodularin. Journal of Plankton Research, 28, 543-550. DOI: 10.1093/plankt/fbi139

Śliwińska, S., Jodłowska, S., Latała, A. 2011. Ekofizjologiczne i allelopatyczne właściwości pikoplanktonowej sinicy Synechococcus sp. Acta Geographica Silesiana, 1, 63-66.

Śliwińska-Wilczewska, S., Pniewski, F., Latała, A. (2016a). Allelopathic interactions between Synechococcus sp. and Nodularia spumigena under different light conditions. Allelopathy Journal, 37(2), 241-252.

Śliwińska-Wilczewska, S., Pniewski, F., Latała, A. (2016b). Allelopathic activity of the picocyanobacterium Synechococcus sp. under varied light, temperature and salinity conditions. International Review of Hydrobiology, 101, 1-9. DOI: 10.1002/iroh.201501819

Żak, A., Kosakowska, A. (2015). The influence of extracellular compounds produced by selected Baltic cyanobacteria, diatoms and dinoflagellates on growth of green algae Chlorella vulgaris. Estuarine, Coastal and Shelf Science, 167, 113-118. DOI: 10.1016/j.ecss.2015.07.038

Abstract

Allelopathic compounds produced by picocyanobacteria could affect the growth and development of biological systems. The main aim of this study was to investigate the influence of unknown allelochemicals obtained from picocyanobacterium Synechocystis sp. BA-153 in monocultures and in mixed cultures. In this study, we demonstrated that Synechocystis sp. BA-153 caused allelopathic effects against other strains of picocyanobacteria. It was found that Synechocystis sp. BA-121 was strongly inhibited by Synechocystis sp. BA-153 in both the mixed culture and cell-free filtrates. On the other hand, the addition of live picocyanobacterial culture of Synechocystis sp. BA-153 stimulated the growth of Synechocystis sp. BA-122. These results showed the allelopathic activity of Synechocystis sp. BA-153, which can cause either the inhibition or stimulation of growth of selected picoplanktonic cyanobacteria.

Key words: allelopathy, picocyanobacteria, Synechocystis sp., growth, mixed culture, monoculture

Received: [2017.05.27]

Accepted: [2017.10.19]

\section{Zjawisko oddziaływania allelopatycznego bałtyckiej pikoplanktonowe j sinicy Synechocystis sp. \\ Streszczenie}

Związki allelopatyczne produkowane przez pikoplanktonowe sinice mogą wpływać na wzrost i funkcjonowanie gatunków fitoplanktonu w ekosystemach wodnych. Głównym celem niniejszej pracy było wykazanie wpływu wciąż nierozpoznanych związków allelopatycznych produkowanych przez pikoplanktonową sinicę Synechocystis sp. BA-153 w monokulturach i hodowlach mieszanych. Na podstawie uzyskanych danych wykazano, że pikoplanktonowa sinica Synechocystis sp. BA-153 wykazywała oddziaływanie allelopatyczne na inne szczepy pikoplanktonowych sinic z tego samego rodzaju. Stwierdzono, że szczep Synechocystis sp. BA-153 silnie hamował wzrost Synechocystis sp. BA-121, zarówno w hodowlach mieszanych, jak i w eksperymentach z dodaniem przesączu. Z drugiej strony, dodanie żywej kultury Synechocystis sp. BA-153 stymulowało wzrost Synechocystis sp. BA-122. Uzyskane wyniki potwierdzają aktywność allelopatyczną Synechocystis sp. BA-153 i wskazują, że może ona zarówno hamować, jak i stymulować wzrost wybranych szczepów pikoplanktonowych sinic.

Słowa kluczowe: allelopatia, pikoplanktonowe sinice, Synechocystis sp., wzrost, hodowle mieszane, monokultury 


\section{Sylwia Śliwińska-Wilczewska}

She is interested in the allelopathy of cyanobacteria and microalgae, in particular of picocyanobacteria Synechococcus sp. In her study, the influence of allelochemicals on the growth, chlorophyll fluorescence, and photosynthesis irradiance curves of different phytoplankton species was investigated. She is also investigating what influences environmental factors have on produced allelopathic compounds on algae and cyanobacteria.

\section{Arkadiusz Knitter}

The field of his interest is allelopathic interactions of picocyanobacterium Synechocystis sp. in monocultures and mixed cultures. He uses a flow cytometer to determine allelopathic interactions between picocyanobacteria.

\section{Daria Cisło}

She is interested in allelopathy of picocyanobacteria, in particular of picocyanobacterium Synechocystis sp. She is investigating what influence allelopathic compounds have on those organisms in monocultures and mixed cultures.

\section{Adam Latała}

He has wide experience in ecophysiology and ecotoxicology of marine benthic and planktonic algae. His particular interest is on the influence of the main environmental factors, such as salinity, temperature, and light on the photosynthesis, photoacclimation, fluorescence, respiration, and the growth of algae from natural communities and cultured under laboratory conditions, including the use of fluorescence techniques to determine algal and cyanobacterial ecophysiology and ecotoxicology. He is the Curator of Culture Collection of Baltic Algae (CCBA) at the Institute of Oceanography, University of Gdańsk. Actually, CCBA maintains more than 100 Baltic strains from three taxonomic groups: blue-green algae, green algae, and diatoms. 